\title{
KATEGORIA RODZAJU GRAMATYCZNEGO W SYSTEMIE JEZYKOWYM, DYSKURSIE I GLOTTODYDAKTYCE
}

\author{
Słowa kluczowe: językoznawstwo, rodzaj gramatyczny, glottodydaktyka, metodyka
}

Streszczenie. Celem artykułu jest opis kategorii rodzaju w języku polskim z trzech perspektyw: systemu gramatycznego, dyskursu oraz glottodydaktyki. W opisie gramatycznym autorka kładzie nacisk na funkcję składniową oraz zasady podziału rzeczowników na rodzaje. Zwraca uwagę na różny sposób językowego symbolizowania płci w dyskursie, który może być rozbieżny z rodzajem gramatycznym. Zauważa różnice między przyswajaniem omawianej kategorii przez rodzimych i nierodzimych użytkowników. $Z$ perspektywy gramatyki pedagogicznej analizuje błędy cudzoziemców w zakresie rodzaju i proponuje ogólne zasady nauczania tej kategorii.

Relacje między glottodydaktyką jako dziedziną badawczą a praktyką dydaktyczną przyczyniają się do coraz bardziej adekwatnego rozumienia przedmiotu badań tej nauki, jakim jest proces nauczania / uczenia się J2 (Wilczyńska, Michońska-Stadnik 2010, s. 31-32). Istotnym czynnikiem warunkującym ten proces jest opracowanie bardziej przystępnej dla osób uczących się gramatyki pedagogicznej. $Z$ tego względu językoznawstwo jest wciąż ważną dziedziną wspierającą dla glottodydaktyki. Dostarcza ono wyjściowej wiedzy do modelowania rozłożonego w czasie procesu stopniowego nabywania kompetencji komunikacyjnej w drugim języku. Modelowanie to jest konieczne, zwłaszcza w przypadku kategorii gramatycznych o znacznym stopniu skomplikowania przy jednoczesnym głębokim wpływie na całą strukturę zdania.

Do kategorii takich w języku polskim z pewnością należy rodzaj gramatyczny. Dostrzegam przynajmniej trzy obszary, które są współzależne i na których można powiązać tę kategorię z kompetencją komunikacyjną, tj. funkcjonowanie rodzaju gramatycznego w systemie językowym, w dyskursie, a poprzez te dwa obszary - również w glottodydaktyce. Celem artykułu jest zebranie głównych

*edyta.paluszynska@uni.lodz.pl, Uniwersytet Łódzki, Wydział Filologiczny, Instytut Filologii Polskiej i Logopedii, Zakład Lingwistyki Stosowanej i Kulturowej, ul. Pomorska 171/173, 90-236 Łódź. 
ustaleń dotyczących kategorii rodzaju w języku polskim (zwłaszcza w gramatyce akademickiej), z zasygnalizowaniem zmian kodowania rodzaju naturalnego we współczesnym dyskursie oraz próba takiego wymodelowania zasad nauczania rodzaju w gramatyce pedagogicznej, aby były przydatne w nauczaniu języka polskiego jako obcego. Modelowanie w tym przypadku rozumiem jako hierarchizację treści ze względu na kryterium ważności danego zespołu reguł na danym etapie nauczania, redukcję elementów lub stopniowe ich wprowadzanie ze względu na poziom zaawansowania. Niniejszy artykuł jest przeglądowy. Przeanalizowano w nim literaturę dotyczącą kategorii rodzaju, poczyniono obserwacje odnośnie do leksykalnego, gramatycznego i słowotwórczego ujmowania rodzaju naturalnego we współczesnym uzusie, a w części analitycznej przytoczono błędy cudzoziemców dotyczące tejże kategorii.

Specyfika kategorii rodzaju w języku polskim wynika ze szczególnego połączenia pierwotnej motywacji semantycznej w podziale rzeczowników żywotnych (ze względu na płeć bądź wiek) z wtórną funkcją składniową pełnioną przez rodzaj wszystkich rzeczowników (również nieżywotnych). Gramatykalizacja kategorii rodzaju oznacza jej obligatoryjność w języku polskim: „Języki różnią się tym, co gramatykalizują, np. mogą gramatykalizować płeć mówiącego i adresata, określoność obiektów (...). Każdy język może wyrazić wszystko, tzn. wszystko, o czym jesteśmy w stanie pomyśleć, ale ponadto musi wyrażać to, co w danym języku podlega gramatykalizacji (...) (Kurcz 2005, s. 28). Jeśli nadawca nie zna jakiegoś leksemu, to może użyć synonimu lub peryfrazy. Kiedy jednak nie zna rodzajów rzeczownika lub nie umie ich prawidłowo przyporządkować, to będzie miał kłopot z całą strukturą zdania, gdyż rodzaj sygnalizuje powiązanie składniowe grup imiennych i przesądza o wzorcu odmiany każdego z rzeczowników. Tak więc kategoria rodzaju gramatycznego, obok kategorii liczby i przypad$\mathrm{ka}$, jest ważnym elementem systemu językowego, ponieważ decyduje o regułach generowania zdań dzięki możliwości wiązania ich składników.

Sposób tego wiązania jest opisany w ramach działu morfologii - fleksji imiennej (GWJP 1998, s. 207-217). Autorzy wymienionego podręcznika akademickiego podają, że rodzaj gramatyczny jest kategorią morfologiczną, która dotyczy odmiennych części mowy, jednak dzieje się to w dwojaki sposób: dla rzeczownika jest kategorią syntaktycznie niezależną, tzn. przysługuje leksemowi we wszystkich formach fleksyjnych; dla czasownika, przymiotnika, liczebnika jest kategorią syntaktycznie zależną, zdeterminowaną przez rodzaj rzeczownika, co oznacza, że te części mowy odmieniają się przez rodzaje. Widać zatem, że nadrzędnym zagadnieniem jest bezbłędne rozpoznanie rodzaju gramatycznego rzeczownika, ponieważ ta cecha decyduje o prawidłowym uzgodnieniu związków syntaktycznych między składnikami wypowiedzenia: podmiotem i orzeczeniem oraz w grupach imiennych. Funkcją rodzaju gramatycznego jest sygnalizowanie związku między składnikami wypowiedzenia zgodnie z intencją nadawcy. Ko- 
nieczna jest znajomość form fleksyjnych czasownika, przymiotnika, liczebnika, ale żeby je wybrać z całego paradygmatu - trzeba znać rodzaj rzeczownika.

Obrazowo można powiedzieć, że rodzaj rzeczownika jest jego wyjątkowym kluczem, który pozwala dopiąc taki łańcuch powiązań między wyrazami w zdaniu, jaki jest zgodny z intencją nadawcy, czyli z sensem, jaki chce przekazać. Obrazuje to przykład: Nauczyciel przynióst uczniowi now-emu/a książę. Sygnalizowanie sensu, czy nadawcy chodzi o nowego ucznia czy o nowa ksiązę jest możliwe dzięki powiązaniu przymiotnika uzgodnionym rodzajem z rzeczownikiem męskoosobowym uczeń bądź żeńskim - książka. Alternatywnie dwukierunkowe powiązanie przymiotnika jest możliwe pomimo tego, że neutralną pozycją przydawki określającej jest prepozycja (nowemu uczniowi, a nie uczniowi nowe$m u$ ). Nieneutralny szyk może jednak uwypuklać określoną strukturę tematyczno-rematyczną tekstu, podkreślać daną treść jako nową, ważną - jest zatem możliwy. W kolejnym przykładzie brak wykładnika predykatywności być dopuszcza powiązanie przymiotnika prorocz(y) z męskonieżywotnym rzeczownikiem sen lub żeńskim rzeczownikiem wróżba: Sen prorocz-y/a dobra wróżbą. Z kolei usłyszane zdanie: *Kiedy wyjechali kobieta? odbiorca w pierwszym momencie potraktuje raczej jako pytanie i zwrot w mianowniku (kobieta) zamiast wołacza (kobieto) niż spójne pytanie o wyjazd kobiety. Powodem jest nieuzgodnienie rodzaju i liczby pomiędzy podmiotem i orzeczeniem (Kiedy wyjechała kobieta?). Obserwacje i ćwiczenia przeprowadzone przez autorkę artykułu w grupach rodzimych użytkowników języka polskiego skłaniają do wniosku, że uzgodnienie rodzaju pomiędzy członami zdania ma pierwszorzędne znaczenie dla zakodowania zamierzonego sensu w jego strukturze.

Wobec powyższych faktów znajomość rodzaju rzeczownika okazuje się bardzo ważna. Jak w swojej monografii reasumuje stan badań nad rodzajem W. T. Stefańczyk: „We współczesnym językoznawstwie polonistycznym współistnieją dwie koncepcje podziału rzeczowników na klasy rodzajowe: tradycyjna, przyjmująca mianownik liczby pojedynczej ${ }^{1}$ za podstawę podziału (...) oraz nowsza, według której biernik liczby pojedynczej stanowi podstawę podziału (...)" (Stefańczyk 2007, s. 17). Do nowszej teorii przychyla się R. Laskowski, który twierdzi: „Podział rzeczowników na klasy rodzajowe (tzn. klasy leksemów o identycznym klasyfikującym rodzaju gramatycznym) jest wyznaczony przez występujące między poszczególnymi rzeczownikami różnice w łączliwości syntaktycznej danego leksemu rzeczownikowego z pewnymi ściśle dla każdego rzeczownika określonymi zbiorami form fleksyjnych leksemów o fleksyjnej kategorii rodzaju gramatycznego. Tym samym podział rzeczowników na klasy rodzajowe (tzn. określenie rodzaju gramatycznego każdego rzeczownika) to podział

${ }^{1}$ Alternatywne rozwiązanie daje I. Bobrowski, uzależniając rodzaj rzeczownika od liczby. W liczbie pojedynczej proponuje trzy rodzaje: męski, żeński i nijaki; w liczbie mnogiej natomiast dwa rodzaje: męskoosobowy i niemęskoosobowy (Bobrowski 2005, s. 87). 
rzeczowników ze względu na ich łączliwość z formami fleksyjnymi przymiotników, czasowników i liczebników" (GWJP 1998, s. 208). R. Laskowski obrazowo porównuje określenie rodzaju gramatycznego rzeczownika do instrukcji, jak dopasować do niego formę fleksyjną podrzędnika. Stąd nie dziwi u niego nazwanie klas rodzajowych - klasami kongruencyjnymi (GWJP 1998, s. 209).

Niezależnie od przyjętych kryteriów, podział rzeczowników na klasy rodzajowe stał się także ważnym elementem językowego obrazu świata. Zauważa się mianowicie, że dokonał się on w rozwoju historycznym języka polskiego ze względu na płeć (rodzaj męski, żeński) i wiek (rodzaj nijaki), ale tylko w obrębie rodzaju męskiego doszły dodatkowe kryteria (osobowość, żywotność), które pozwoliły na ukształtowanie się trzech rodzajów męskich: męskoosobowego, męskożywotnego, męskonieżywotnego). Tym samym w polskim systemie językowym utrwalił się niesymetryczny rozkład gramatykalizowanych kategorii w obrębie rodzaju męskiego (trzy kategorie: płeć, osobowość, żywotność) i żeńskiego (jedna kategoria: płeć). W dyskursie publicznym, tekstach urzędowych wiele form męskich używanych jest zarówno w odniesieniu do mężczyzn, jak i domyślnie - w odniesieniu do kobiet, np. klient, abonent, podatnik, kredytobiorca, pracodawca. Brak form żeńskich dotyczy zwłaszcza nazw prestiżowych stanowisk, stopni, tytułów, np. prezydent, burmistrz, premier, minister, prezes, adiunkt, doktor ${ }^{2}$. W tych wypadkach wykładnikiem rodzaju naturalnego osoby płci żeńskiej jest wprowadzenie nieodmienności rzeczownika w odróżnieniu od odmienności tejże nazwy użytej w odniesieniu do mężczyzny, np. Spotkaliśmy się z doktorem Nowakiem - kiedy chodzi o mężczyznę, ale: Spotkaliśmy się z doktor Nowak - kiedy chodzi o kobietę. Można wywnioskować, że pragmatycznie występuje potrzeba - i w tych przypadkach - odróżnienia płci, ale słowotwórcze środki są wprowadzane często z pewnym oporem. Czasem nazwy żeńskie odbierane są jako potoczne, np. dyrektorka, doktorka, profesorka, prezeska, a czasem jako sztuczne, np. ta ministra, politolożka, psycholożka, teolożka, socjolożka. Inne jednak przyjęły się bez oporów, np. klientka, posłanka. Niezależnie od różnej oceny tego zjawiska w ramach kulturowych trendów takich jak: konserwatyzm, patriarchat, feminizm, gender, seksizm, poprawność polityczna, trzeba przyznać, że kategoria rodzaju w języku polskim jest jednym z nielicznych zagadnień gramatycznych, które wkroczyły do dyskursu publicznego. Są przedmiotem szczególnej refleksji nad normą dyskursu publicznego i wpływem klasyfikujących kategorii języka na społeczną świadomość.

Poza zagadnieniem kodowania płci w języku rodzaj jest przedmiotem rozważań w obrębie normy językowej. Ze względu na arbitralnie przypisany rodzaj gramatyczny do rzeczowników nieżywotnych, a nawet do niektórych rzeczowników żywotnych (por. trup - rodzaj męskożywotny ze względu na synkretyzm B=D w 1. poj.), poprawne przyporządkowanie tej kategorii konkretnemu rzeczowniko-

\footnotetext{
${ }^{2}$ Por. Brzozowska 2005, s. 39.
} 
wi może nastręczać trudności. Ich zakres i komunikacyjne następstwa są jednak różne w przypadku rodzimych użytkowników języka i cudzoziemców. W przypadku Polaków rodzaj jest problemem z dziedziny kultury języka dotyczącym rzeczowników rzadkich, należących do różnych odmian języka bądź obcego pochodzenia (np. derby, piszczel, żołądź, tabu). Problemem może być też wahanie w obrębie wyboru: rodzaj męskożywotny czy męskonieżywotny, np. sms, email, kotlet. Wybór odpowiedniego rodzaju skutkuje realizacją formy wzorcowej: dostałam SMS, wystał email, zjadt kotlet (rodzaj męskonieżywotny) lub dopuszczalnej, użytkowej dostałam SMS-a, wystat maila, zjadt kotleta (rodzaj męskożywotny). Błędy u rodzimego użytkownika języka mogą pojawić się również w obrębie rzeczowników zbiorowych, kiedy np. jest mowa o zbiorze osób płci męskiej, ale rzeczownik nazywający go ma gramatyczny rodzaj żeński (Do przewodnika podeszła grupa studentów. Szybko otoczyli* go, czekając na opowieść). Mimo kilku miejsc trudnych, błędy z kategorią rodzaju są dla rodzimych użytkowników języka problemem marginalnym. Wynika to $\mathrm{z}$ faktu, że tacy użytkownicy mają w umyśle wiele przykładów poprawnych tekstów, w których na podstawie dopasowania członów zależnych w składni zgody - rodzaj po prostu widać (jeśli czerń, to głęboka, a więc rodzaj żeński; jeśli słoń, to ogromny, a więc rodzaj męski).

Podział rzeczowników na klasy kongruencyjne ze względu na syntaktyczną łączliwość rzeczowników z formami fleksyjnymi przymiotników, czasowników i liczebników nie jest identyczny (GWJP 1998, s. 209). Jednak za podstawę klasyfikacji rodzajowej rzeczowników polskich przyjęto łączliwość form biernika obu liczb. Dodatkowo rodzaje charakteryzują się typowym dla każdej klasy zestawem synkretyzmów. W wyniku powyższych kryteriów polskie rzeczowniki gramatykalizują rodzaj w pięciu podkategoriach: rodzaj żeński, nijaki, męskoosobowy, męskożywotny, męskonieżywotny. Rzeczowniki żeńskie charakteryzują się synkretyzmem celownika i miejscownika 1. poj. (C. komu? kobiecie = Msc. o kim? o kobiecie) oraz mianownika i biernika l. mn. (M. kto to jest? kobiety = B. kogo widzę? kobiety). Rzeczowniki o rodzaju nijakim charakteryzują się synkretyzmem mianownika i biernika obu liczb (M. co to jest? pole, pola = B. co widzę? pole, pola). Wyróżniany tradycyjnie w gramatyce szkolnej rodzaj męski rozdziela się na 3 rodzaje. W rzeczownikach męskoosobowych zachodzi synkretyzm biernika i dopełniacza w obu liczbach (B. kogo widzę? pana, panów = D. kogo nie ma? pana, panów). Rzeczowniki męskożywotne charakteryzuje synkretyzm biernika i dopełniacza w 1. poj. (B. co widzę? konia = D. czego nie ma? konia), natomiast w 1 . mn. występuje synkretyzm biernika i mianownika (B. co widzę? konie = M. co to jest? konie). Rodzaj męskonieżywotny (np. kamień) ma układ synkretyzmów taki, jaki charakteryzuje rodzaj nijaki, przy innym zestawie końcówek fleksyjnych (por. duże pole, ale duży kamień). Jak widać, nie jest to system prosty, dlatego nawet dzieci w trakcie przyswajania języka mogą czasem błędnie przypisać rodzaj, np. Mamo, tu jest szczura*! (r. ż.) Jednak wchodzenie w interakcję daje 
szansę na korektę, dziecko jest poprawiane i w rezultacie osłuchania z językiem uczy się z czasem rodzaju najczęściej używanych rzeczowników.

Tego rodzaju doświadczeń z językiem, zwłaszcza na początkowych etapach nauki, nie ma obcokrajowiec. A zatem tworzenie przez niego klas kongruencyjnych w wyniku porządkowania dużej liczby przykładów poprawnego użycia grup nominalnych i łączenie ich w rodzaje na podstawie powtarzalności form fleksyjnych określników jest mało prawdopodobne. Osoba ucząca się języka powinna mieć innego rodzaju wskazówki co do rodzajowej przynależności rzeczownika. Bez nich nabycie kompetencji gramatycznej skazane jest na pamięciowe opanowanie dodatkowego elementu33. Uczący się musi bowiem zapamiętać dźwiękową postać rzeczownika, postać graficzną, powiązać je ze znaczeniem i dodatkowo przypisać rzeczownikowi jeden z pięciu rodzajów. Jest to obciążenie pamięci, a więc można przewidzieć prawdopodobieństwo błędów. Potwierdzeniem tego faktu są przykłady zebrane przez autorkę artykułu w pracach studentów Studium Języka Polskiego dla Cudzoziemców UŁ ${ }^{4}$.

W zdaniu, które wymagało uzupełnienia:

Naukowcy opublikowali właśnie w „Nature” wyniki badań dotyczacych mutacji genetycznych, które przynieśli do Europy ......................... (pierwszy rolnik) (uzupełnienie poprawne: pierwsi rolnicy),

studenci obcojęzyczni wpisywali:

Naukowcy opublikowali właśnie w „Nature” wyniki badań dotyczacych mutacji genetycznych, które przynieśli do Europy pierwszego rolnika.

Naukowcy opublikowali właśnie w „Nature” wyniki badań dotyczacych mutacji genetycznych, które przynieśli do Europy pierwszych rolników.

Naukowcy opublikowali właśnie w „Nature” wyniki badań dotyczacych mutacji genetycznych, które przynieśli do Europy pierwsze rolniki*.

W dwóch pierwszych zdaniach rozerwanie składni zgody pomiędzy członem przynieśli a członem pierwsi rolnicy na skutek nieuzgodnienia czy nieznajomości kategorii rodzaju i użycie biernika zamiast mianownika w 1. poj. lub 1. mn. zmienia strukturę i sens zdania, ponieważ z podmiotu zdania (pierwsi rolnicy) czyni dopełnienie (pierwszego rolnika / pierwszych rolników). W trzecim zdaniu żądane wyrażenie zachowuje funkcję dopełnienia, jednak rodzaj jest przypisany błędnie, nie jest to rodzaj męskoosobowy. Brak poprawnej formy rodzaju męskoosobowego rzeczownika bądź jego członów określających występuje również w poniższych przykładach.

\footnotetext{
${ }^{3}$ Trudność ta pojawia się również w innych językach mających rodzaje. Autorka spotkała się z żartobliwym aforyzmem na temat nauczania języka niemieckiego: „Byliby Niemcy z nas, gdyby nie der, die, das". Tę rymowankę należy rozumieć jako zdiagnozowanie szczególnego miejsca trudnego w nabywaniu kompetencji w języku niemieckim. Rodzaj rzeczowników nieżywotnych jest często różny w języku polskim i niemieckim, por. słońce (r. n.), die Sonne (r. ż); nos (r. m.), die Nase (r. ż).

${ }^{4}$ Prace zostały mi udostępnione przez dra Mateusza Gaze.
} 
Mieli jasna skórę, ciemne oczy i byli wyżsi niż Europejczyki*. (brak alternacji k:c oraz $i: y$ )

Przeszło 30 lat temu ostatni neandertalczycy wyginęli - ciagle trwaja dyskusje, czy wybili ich nasze* przodkowie. (niepoprawna forma rodzajowa zaimka nasz, rodzaj niemęskoosobowy zamiast męskoosobowego, popr. nasi)

Przy urządzaniu pałacyku w Wilanowie pracowali najlepsze* artyści tamtych czasów.

Strażacy sa znacznie odważniejsze*. (poprawnie najlepsi, odważniejsi)

Najpierw panowie wysiadly* na złym przystanku, a potem przeszly* ulice na czerwonym świetle. (poprawnie rodzaj męskoosobowy: wysiedli, przeszli).

W obrębie rzeczowników rodzaju męskoosobowego w M. 1. mn. systemowo występują końcówki równoległe: -i/y, -e, -owie. Ich zgodna z normą dystrybucja, a więc wybór właściwej końcówki, również nastręcza cudzoziemcom trudności.

Przeszło 30 lat temu ostatni neandertalczycy wyginęli - ciagle trwaja dyskusje, czy wybili ich nasze przodki*; (...) czy wybili ich nasi przodcy* (końcówka -il-y, zamiast popr. -owie).

Badania pokazuja, że pasterzy*, którzy ujarzmili koni*, mieli jasna skórę. (pasterzy: końcówka -i/-y, zamiast -e), (forma koni może być błędnym wyborem synkretyzmu biernika i dopełniacza $\mathrm{B}=\mathrm{D}$ w 1 . mn., który jest typowy dla rzeczowników męskoosobowych, zamiast synkretyzmu biernika i mianownika $\mathrm{B}=\mathrm{M}$ w $\mathrm{l}$. $\mathrm{mn}$. typowego dla rodzaju męskożywotnego).

W kolejnych przykładach również niedostatecznie rozróżniono rodzaj męskożywotny od męskoosobowego. Świadczy o tym niewłaściwa końcówka fleksyjna biernika 1 . mn., który w rzeczownikach męskożywotnych powinien być w języku polskim równy mianownikowi, a tymczasem jest równy dopełniaczowi, jak w rzeczownikach rodzaju męskoosobowego.

Europę skolonizowały trzy ludy z gatunku Homo sapiens, których spadkobiercami jesteśmy prawie wszyscy. $W$ Europie udomowili oni wilków*.

Kolejna fala emigracji przyniosła Europie pierwszych rolników, którzy nie tylko uprawiali ziemię, ale także hodowali dzikich zwierzat**.

Badania pokazuja, że pasterze, którzy ujarzmili koniów*, mieli jasna skórę (tu dodatkowo jest zła końcówka D. 1. mn. -ów zamiast $-y /-i$ ).

Wyraźną trudność sprawia uzgodnienie formy rodzajowej podrzędnika do rzeczowników, takich jak osoba, zwłaszcza kiedy występuje on w liczbie mnogiej lub z liczebnikiem nieokreślonym, np. parę. Trudność polega na tym, że gramatyczny rodzaj żeński rzeczownika osoba nie przeszkadza w symbolizowaniu nim mężczyzn, co dezorientuje uczących się.

Parę osób przed chwila zaczęli* się kręcić przed sklepem spożywczym.

Podjąc taka decyzję moga tylko młodzi* osoby. Oni* licza na większe możliwości.

Kolejnym problemem jest słaba rozpoznawalność rodzaju nijakiego, który jest rodzajem najmniej licznie reprezentowanym w polskim słownictwie 5 .

5 Spośród rzeczowników wyekscerpowanych przez W. Stefańczyka z Uniwersalnego słownika języka polskiego, pod red. S. Dubisza tylko 10 proc. stanowiły leksemy rodzaju nijakiego (Stefańczyk 2007, s. 48). 
Gdyby przyjęcie było udana*, powtórzyłbym je kilka razy.

Ryzyko zakażenia byłoby minimalny*.

Do form trudnych należą również pluralia tantum:

Chciałem zaprosić pana na moje urodziny, który* odbędzie o* stycznia.

W przytoczonych przykładach błędy w zakresie kategorii rodzaju skutkują nie dość wyraźnym zasygnalizowaniem składni zgody pomiędzy członami zdania i w rezultacie przekaz sensu wymaga od odbiorcy większego wysiłku interpretacyjnego. Błędy tego rodzaju wyraźnie wskazują na brak osłuchania się z językiem, co jest typowe dla nauczania w warunkach szkolnych. Uczący się języka jako obcego wymagają zatem w nabywaniu kompetencji komunikacyjnej zwiększonego udziału świadomej wiedzy metajęzykowej, która mogłaby te braki zrównoważyć. Uczący się - zamiast wnioskować o rodzaju gramatycznym na postawie kontekstów łączliwości rzeczownika - mógłby wykorzystać jego postać fonologiczną i morfologiczną. $Z$ takiego założenia wychodzą autorzy podręczników do gramatyki dla cudzoziemców. Z. Kaleta, omawiając końcówki rzeczownika w mianowniku, zaznacza że informują one o rodzaju gramatycznym. Autorka najpierw podaje typowe końcówki dla poszczególnych rodzajów, a potem sygnalizuje kilka wyjątków (Kaleta 1995, s. 68). M. Kita proponuje dwustopniowy podział rodzaju rzeczownika: najpierw jest rodzaj żeński, nijaki i męski, a na drugim poziomie ogólności - rodzaj męski rozgałęzia się na męskoosobowy, męskożywotny i męskonieżywotny (Kita 1998, s. 96). L. Madelska również traktuje żywotność i osobowość rzeczowników męskich jako dodatkową cechę klasyfikacyjną w obrębie rodzaju męskiego (Madelska, Warchoł-Schlottmann 2013, s. 73-75). Z badań językoznawców wynika, że to właśnie te cechy są najistotniejszymi wskazówkami: „o przynależności leksemu do określonej klasy rodzajowej decyduje głównie postać fonologiczna i morfologiczna rzeczownika w M. 1. poj. Jedynie w wypadku stosunkowo nielicznej grupy rzeczowników osobowych czynnikiem decydującym jest również kryterium semantyczne, tj. rodzaj naturalny" (Stefańczyk 2007, s. 20). Dzięki badaniom ilościowym ${ }^{6}$ na obecnym etapie można sformułować wskazówki dla cudzoziemców mających trudności z opanowaniem rodzaju w polszczyźnie:

- Jeśli rzeczownik kończy się w M. 1. poj. końcówką $\varnothing$, to najczęściej ma rodzaj męski (z nielicznymi wyjątkami, np. kolej, noc, mysz, twarz, ciecz, rzeczowniki zakończone na -ość - r.ż.);

- Jeśli rzeczownik jest zakończony w M. 1.poj. na - $a$, to najczęściej przyjmuje rodzaj żeński (z wyjątkiem nielicznych rzeczowników osobowych, np. turysta, sędzia, mężczyzna - r.m.);

- Jeśli rzeczownik jest zakończony na -i, to reprezentuje rodzaj żeński (z wyjątkiem nieodmiennych rzeczowników obcych, np. alibi, salami -r. n.);

${ }^{6}$ W. Stefańczyk zbadał 44000 rzeczowników (Stefańczyk 2007, s. 14). 
- Jeśli rzeczownik jest zakończony w M. 1.poj. na -e, to bezwyjątkowo przyjmuje rodzaj nijaki;

- Jeśli rzeczownik jest zakończony w M. 1.poj. na -o, to przyjmuje rodzaj nijaki (z wyjątkiem nielicznych rzeczowników ekspresywnych, np. misio, wujcio - r.m.) ;

- Rzeczowniki zakończone na -um przyjmują rodzaj nijaki (z wyjątkiem kilku rzeczowników pochodzenia obcego, np. album, kostium - r.m.);

- Rzeczowniki zakończone na -ę reprezentują rodzaj nijaki (wyjątkiem rzeczownika ksiąze - r.m.).

Korelacja między morfologiczną, fonologiczną postacią rzeczownika a jego rodzajem bez wątpienia dostarcza reguł pomocnych w opanowaniu polskiego systemu gramatycznego przez cudzoziemca ${ }^{7}$. Zwłaszcza, że jest przydatna w większej liczbie leksemów niż motywacja semantyczna (płeć, wiek). Reguły te, według badań W. Stefańczyka, obejmują w różnych grupach od 92\% do 99\% rzeczowników, nie są więc bezwyjątkowe. Dodatkowo należy wziąć pod uwagę synkretyzm form biernika rzeczowników rodzaju męskiego w 1. poj. i 1. mn., który różnicuje rodzaj męskożywotny i męskoosobowy od męskonieżywotnego. Przy czym w liczbie pojedynczej ważniejsza jest opozycja żywotność/nieżywotność (por. widzę pana, studenta, $k$ ta $\mathrm{B}=\mathrm{D}$, ale widze kwiat $\mathrm{B}=\mathrm{M}$ ), a w liczbie mnogiej natomiast - opozycja osobowość/nieosobowość (por. widze panów, studentów $\mathrm{B}=\mathrm{D}$, ale widzę koty, kwiaty $\mathrm{B}=\mathrm{M}$ ). Kryterium semantyczne zaś jest bardziej pomocne w rozpoznawaniu rodzaju męskoosobowego niż męskożywotnego, gdyż „gramatyczną żywotność” zyskuje wiele klas rzeczowników semantycznie nieżywotnych, np. nazwy marek samochodów, walut, tańców, potraw i inne (por. kupit opla, wydał dolara, tańczy oberka, je tatara). Niewątpliwie może być to mylące dla cudzoziemca.

Model nauczania polskiego rodzaju dla potrzeb glottodydaktyki powinien przede wszystkim uwzględniać rozległość danej reguły gramatycznej (jak często jest stosowana, czym grozi jej nieznajomość) oraz poziom docelowy rozwoju kompetencji, mierzony skalą ESOKJ. Biorąc pod uwagę poziom kompetencji i rangę błędów wynikających z nieznajomości kategorii rodzaju, można przyjąć zasadę stopniowego rozgałęziania klas w obrębie rodzaju rzeczownika: najpierw podział na rodzaj męski, żeński i nijaki, dopiero potem podział rodzaju męskiego ze względu na kryteria osobowości, żywotności i nieżywotności ${ }^{8}$. W obrębie ro-

${ }^{7}, \mathrm{~W}$ ujęciu jakościowym rodzaj gramatyczny charakteryzuje się bardzo wysokim stopniem regularności. Odzwierciedlają to zarówno nowo zaadaptowane rzeczowniki typu e-mail, axel, euro, dostosowując swój rodzaj do dominujących ilościowo grup leksemów, jak i dokonujące się procesy wyrównawcze, w wyniku których nietypowe dla współczesnej polszczyzny leksemy typu głą, skrzel, suchorośl zmieniają postać na głębia, skrzele, suchorośle" (Stefańczyk 2007, s. 157).

${ }^{8}$ Por. wymogi poprawności gramatycznej odnoszące się do poszczególnych poziomów biegłości. Na poziomie A1 jest mowa o trzech rodzajach, natomiast dodatkowe podziały rodzaju męskiego ze względu na żywotność i osobowość są wymagane na poziomie A2 (https://www.infor. pl/akt-prawny/DZU.2016.061.0000405, rozporzadzenie-ministra-nauki-i-szkolnictwa-wyzszego-wsprawie-egzaminow-z-jezyka-polskiego-jako-obcego.html. [20.03.2018]. 
dzaju męskiego ważniejsza jest opozycja osobowość/nieosobowość ze względu na potrzebę komunikacji, a więc ze względu na powiązanie z rodzajem naturalnym i potrzebę realizacji funkcji nominatywnej. Należy jednak podkreślić, że z uwagi na konieczność uzgodnienia pomiotu z orzeczeniem podział rzeczowników przynajmniej na rodzaj męski, żeński i nijaki powinien być wprowadzony od najwcześniejszych etapów nauczania. Jeśli chodzi o wprowadzanie rodzajów rzeczownika, to dla obcokrajowców lepiej sprawdzi się klasyfikacja na podstawie cech morfologicznych (nawet pomimo wyjątków) niż na podstawie klas kongruencyjnych, ponieważ cudzoziemcom na ogół brakuje naturalnego osłuchania się z językiem. Ze względu na kryterium ekonomiczności warto najpierw podać ogólne reguły ujmujące korelację między postacią morfologiczną rzeczownika a rodzajem, a dopiero później wprowadzać wyjątki (chodzi o kilkuprocentowe grupy rzeczowników mających rodzaj inny niż ponad $90 \%$ rzeczowników o analogicznej postaci morfologicznej). Niemniej jednak przy kolejności nauczania wyjątków należy wziąć także pod uwagę częstotliwość użycia danego rzeczownika. Morfologicznie nietypowe nadanie rodzaju rzeczownikom często używanym, takim jak: mężczyzna, artysta (rodzaj męski, choć większość rzeczowników na - $a$ ma rodzaj żeński); $r z e c z$, noc (rodzaj żeński, choć większość rzeczowników na spółgłoskę ma rodzaj męski), wymusza mimo ich wyjątkowości relatywnie wczesne wprowadzenie. Według wymagań certyfikatowych najpóźniej na poziomie A2.

\section{BIBLIOGRAFIA}

Bobrowski I., 2005, Rodzaj gramatyczny rzeczownika a jego liczba, „Język Polski”, z. 2, s. 83-89.

Brzozowska D., 2005, Kategoria rodzaju we współczesnym języku polskim, „Język Polski”, z. 1, s. $36-42$.

Gramatyka wspótczesnego języka polskiego. Morfologia (GWJP), 1998, R. Grzegorczykowa, R. Laskowski, H. Wróbel (red.), Warszawa.

Kaleta Z., 1995, Gramatyka języka polskiego dla cudzoziemców, Uniwersytet Jagielloński, Kraków.

Kita M., 1998, Wybieram gramatykę! Gramatyka języka polskiego w praktyce (dla cudzoziemców zaawansowanych), t. 1, Katowice.

Kurcz I., 2005, Psychologia języka i komunikacji, Warszawa.

Madelska L., Warchoł-Schlottmann M., 2013, Odkrywamy język polski. Gramatyka dla uczacych (się) języka polskiego jako obcego, Kraków.

Rozporządzenie Ministra Nauki i Szkolnictwa Wyższego z dnia 26 lutego 2016 r. w sprawie egzaminów z języka polskiego jako obcego, https://www.infor.pl/akt-prawny/DZU.2016.061.0000405,rozporzadzenie-ministra-nauki-i-szkolnictwa-wyzszego-w-sprawie-egzaminow-z-jezyka-polskiego-jako-obcego.html [20.03.2018].

Stefańczyk W. T., 2007, Kategoria rodzaju i przypadka polskiego rzeczownika. Próba synchronicznej analizy morfologicznej, Kraków.

Wilczyńska W., Michońska-Stadnik A., 2010, Metodologia badań w glottodydaktyce. Wprowadzenie, Kraków. 


\section{Edyta Patuszyńska}

\section{CATEGORY OF GRAMMATICAL GENDER IN THE POLISH LANGUAGE SYSTEM, DISCOURSE AND GLOTTODIDACTICS}

Keywords: linguistics, grammatical gender, glottodidactics, methodology

Abstract. The aim of the article is to describe the category of gender in Polish from three perspectives: the perspective of the grammatical system, of discourse and of glottodidactics. In the grammatical description, the author emphasizes the syntactic function and the rules for dividing Polish nouns into genders. She draws attention to different ways of linguistic symbolization of gender in a discourse, which may be divergent from the grammatical gender. She notices differences between the acquisition of the category in question by native and non-native users. From the perspective of pedagogical grammar, she analyzes the mistakes of foreigners in terms of gender and proposes general principles of teaching this category. 